\title{
水溶性ガス田における透水量係数の推定
}

\author{
秋林智* 軽 部幸 一**・原淳 治***
}

(昭和 61 年 2 月 5 日受付，61年 3 月 18 日受理)

\section{Estimation of Transmissivity in the Water-Dissolved Gas Field}

By

Satoshi AKIBAYASHI*, Koichi KARUBE** and Junji HARA***

\begin{abstract}
The spatial distribution of transmissivity in the water-dissolved gas field ( $G_{6}$ formation) in the Nishikanbara district, Niigata prefecture, was estimated using time histories of the groundwater heads which were calculated from the production data such as flow rate, gas-water ratio and wellhead. pressure etc. at a number of wells. A quasi-linear approach was used to estimate the transmissivity.

The estimated values of transmissivity were in the region of $2.0 \times 10^{-4} \sim 7.8 \times 10^{-2} \mathrm{~m}^{2} / \mathrm{s}$, and in the same accuracy as the values of transmissivity which were estimated using time histries of the groundwater heads including the errors which were expressed by random numbers of normal distribution $N\left(0,4.9^{2}\right)$.
\end{abstract}

\section{1. まえがき}

水溶性ガス田に㧍ける産出挙動や還元水の拡がりなど の予測には，広域の地下水流動の解析が必要である。こ の解析には，透水量係数や貯留係数などの带水層パラメ 一タは不可欠な要素である。

従来このパラメータの分布は，地下水頭の観測倠を用 いて推定され，その推定法には線形計画法 (COATS, et $a l ., 1970$ ), 準線形近似法(DIETESFANO, et al., 1975), 影響保数法 (BECKER, et al., 1972) などの種々の方法 がある。しかしながら水溶性ガス田ではガスりフト井や ポンプ井による生産方式を採用しているために生産時に 牤ける氷頭の測定が難しく，上記の方法による透水量係 数の推定は未だなされていない。

本研究は，ガスリフト井などの生産データを有効に利 用して準線形近似法により水溶性ガス田の透水量係数の 空間分有の推定を行うとともにその值の精度について検 討したものである。

\section{2. 水溶性ガス田の概要}

\section{1 地 簤 構 造}

本研究でとりあげた新潟県西蒲原地区の水溶性ガス目

\footnotetext{
* 秋田大学鉱山学部

*** 秋田大学大学院鉱山学研究科 (現日本鉱業秝)

**** 東邦天然ガス株式会社
}

は，新潟平野のなかで広範囲にわたって発達分布する新 潟水溶性ガス田の一部をなすものであり，その地質構造 について概説すると次のと拉りである。

新鼬军野は日本海側新第三系を形成する堆積盈地でる り，平野部に招いては，新第三紀層の上位に砂，礫，粘 土により構成される第四紀層が厚く壦皘し最上部は厚さ $150 \mathrm{~m}$ 前後の沖積層が不整合に覆っている。

西蒲原地区は，新潟水溶性ガス田のなかのはぼ中央部 にあり，本地区一帯の地質構造は，巨視的にみて新潟向 斜構造の東翼の底部近くに位置して，全般的に北西方向 に向かって緩い傾斜を示している。

第四紀層款よび新第三紀層の上部のなかにある砂碟带

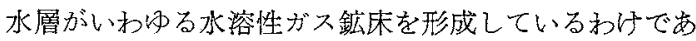
るが，第四紀層中には大別して $\mathrm{G}_{1}, \mathrm{G}_{2}, \mathrm{G}_{3}, \mathrm{G}_{4}, \mathrm{G}_{4-1}, \mathrm{G}_{5}$ の6つのガス層が存在しており，このらら $G_{1}$ 層は沖積 層の基底䃯とみられ，さらに $\mathrm{G}_{5}$ 層は洪積層 (魚濯層群) と下位の新第三紀層との境界に相当するすのといわれて いる。

新第三紀層上部は灰色泥岩で代表される灰爪層となる が，本層のなかで発達する $\mathrm{G}_{5-1}, \mathrm{G}_{6}$ 買の 2 層は層厚の 厚い砂磷岩からなり，上位の $\mathrm{G}_{5}$ 層と合わせて本地区の 主力の稼行ガス層となっている。

$\mathrm{G}_{1} \sim \mathrm{G}_{5-1}$ 層玉での各ガス層については, 生産井, 還 元并とるこれらをそれぞ机単層仕上げした坑井が少ない ため本研究の対象としては不適当と思われるが，G $\mathrm{G}_{6}$ 層は 
生産井，還元井ともこれを単独にとらえて和り，本研究 ではこの $\mathrm{G}_{6}$ 層をとりあげ，その透水量係数の空間分布 を推定することにする。

な招，G6 層は碎岩拉よび粗粒砂交り細礫岩により構 成されているが，その分布範囲はある程度限られてお 句，海岸附近で尖減し内陸側氏向かって桩がっていると みなされている。

\section{2 坑井配置}

図 1 は， $\mathrm{G}_{6}$ 層の坑井配置である。图中の W1 W8 は 既存の生産井，W9〜W17 は既存の還元井である。また A1，A2 は第一次企業化実験でのそれぞれ生産井，還元 井であり，両坑井は昭和 46 年から稼働している。B1〜 B 3 は第二次企業化実験での生産井，B4〜B6は還元井 ですり，いずれの坑井も昭和55年から稼衝している。そ の他 $\mathrm{O}$ ～O4の 4 坑井は $\mathrm{G}_{6}$ 層を対象とした地沈観測井 である。

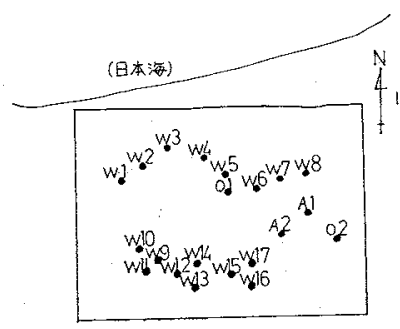

82

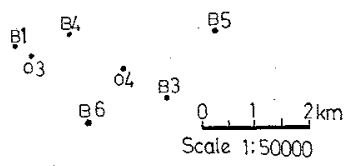

図 $1 \mathrm{G}_{6}$ 層の坑井配置図(東邦天然ガス侏，1985)

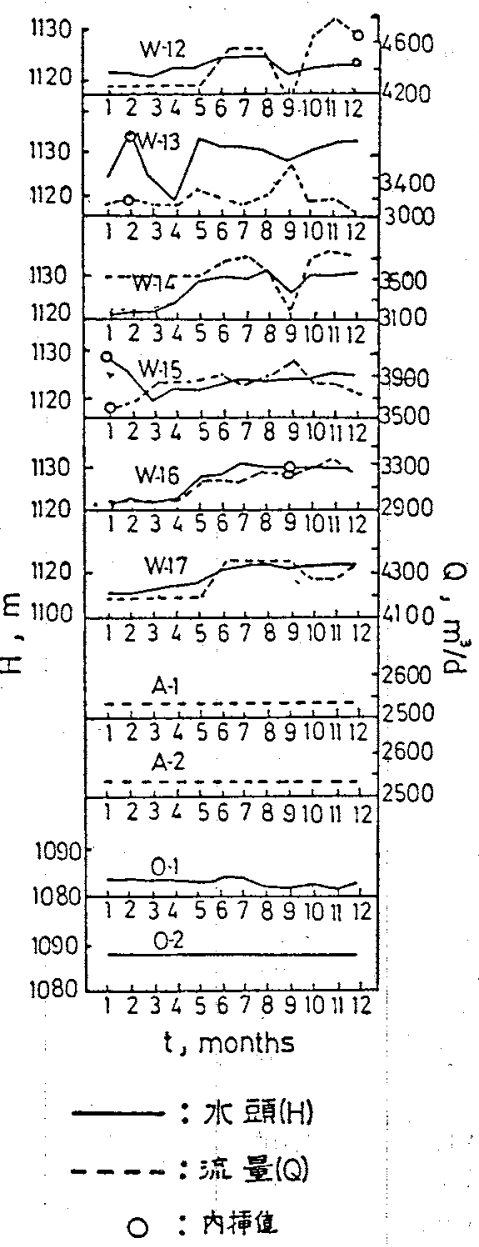

図 2 揚水量执よび压入水量の测定值と水頭の算定值（昭和58年） 


\section{3 生産データ}

今回本研究では前述の既存井17坑并，第一次企業化聿 験井 2 坑井, 地沈観测井 2 坑井 (O1, O2) の合計21坑 井の生産データを利用できた（東邦天然がス椮，1985； 新潟県生活環境部公害規制課，1984)。

(a) 脏井データ

W1〜W8 の生産井はガスリフト方式, A1 の生産井は ポンプ方式であり，W9〜W17，A2の各還元井はポンプ により区入している。表1Kはをれらの坑井の梁度，ス トレーナ中央深度, ケーシング直径, リフト管深度, り フト管㨁径等を示す。

(b) 生産データ

坑底压力解析に使用した生産データは，昭和58年に米 ける揚水量, リフトガス量, 産出がス水比, 王入水量等 の時間的変化である。ただしこれらのデータのらら揚水 量扣よび圧入水量の文図 2 (破線)に示す。図中の○印 は欠測部のスプライン補間 (FORSYTHE, et al., 1978) による内㨀值である。

\section{3. 坑底圧力の解析}

生産井および還元井の流動坑底左力を前述の坑井就よ び生産データを用いて解析する方法について簡単に述べ る。なお生産井就よび還元井はセメント・ライニングを
施している。

(a) ガスリフト井は，ガス就よび水の二相流であり， その流動解析は ORKISZEWSKI (1967) の解法に従った。 この解法は，坑口に和ける流量，ガス水比，压力を与文 て坑井内压力分布を求めるるので，流れの型とガスの流 れのすべりを考慮している。

(b) 還元井の流動琓底圧力は次式により求めた。

$$
P_{w f}=\left(\frac{D \cdot \rho}{10}+P_{w h}\right)-P_{f r}
$$

ここでは $P_{w f}$ は流動坑底生力， $P_{w h}$ は坑口压力（测定 值 (東邦天然がス(橉，1985) を用いた)，P P は摩擦压 力損失（池田公式 (本間他，1962）を用いた）， $\rho$ は僄元 水の密度 $\left(=1.02 \mathrm{~g} / \mathrm{cm}^{3}\right.$ ) (天然がス鉱業会新潟支部, 1973），Dはストレーナの中央樑度（表 1 参照）である。 以上の(a)叔よび(b)の方法による生産井拉よび還元井の 流動坑底圧力の計算結果を水頭に換算し，まとめて図 2 (実線)に示主。ただし A1，A2の坑井圧力はデータ不 足のために計算できなかった。したがって最適透水量係 数の算定には両境井の揚水量, 圧入水量（図 2 参照）の みを利用して水頭は用いていない。な和本地区は場所火 よって約 $\pm 0.5 \mathrm{~m}$ 程度の標高差があるけれども，各坑井 に拈りる坑口の標高については測定データが得られなか ったので水頭の換算にあたってはすべての坑井において 坑口の標高を一様に海水面にとり，その面から $1,100 \mathrm{~m}$

表 1 坑 并 デー タ

\begin{tabular}{|c|c|c|c|c|c|}
\hline 坑韭名 & $\begin{array}{c}\text { 坑 井 深 度 } \\
\mathrm{m}\end{array}$ & $\begin{array}{c}\text { ケーシング祬 } \\
\mathrm{mm}\end{array} \mid$ & $\begin{array}{c}\text { リフト管深度 } \\
\mathrm{m}\end{array}$ & $\begin{array}{c}\text { リフト管径 } \\
\mathrm{mm}\end{array}$ & 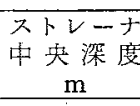 \\
\hline W 1 & 1,029 & 194 & 100,113 & 25 & 998.0 \\
\hline W 2 & 1,040 & 194 & 118,120 & 27,28 & $1,010.2$ \\
\hline W 3 & 1,029 & 194 & 100,112 & 25 & $1,002.8$ \\
\hline W 4 & 1,017 & 194 & $112,124,132,140$ & 25 & 992.5 \\
\hline W 5 & 1,001 & 218 & $98,98.4,108$ & 25,31 & 975.7 \\
\hline W 6 & 995 & 194 & 128,136 & 31,28 & 954.6 \\
\hline W 7 & 991 & 194 & $92,100,114$ & 25 & 955.8 \\
\hline W 8 & 983 & 194 & 90 & 25 & 952.0 \\
\hline W 9 & 1,025 & 194 & & & 999.8 \\
\hline W10 & 1,077 & 194 & & & $1,049.0$ \\
\hline W11 & 1,036 & 194 & & & $1,007.8$ \\
\hline W12 & 1,025 & 194 & & & 992.3 \\
\hline W13 & 1,032 & 194 & & & $1,005.0$ \\
\hline W14 & 1,034 & 194 & & & 994.1 \\
\hline W15 & 1,008 & 194 & & & 979.6 \\
\hline W16 & 1,009 & 194 & & & 981.2 \\
\hline W17 & 1,013 & 194 & & & 983.7 \\
\hline A 1 & 976 & & & & 941.8 \\
\hline A 2 & 975 & & & & 950.8 \\
\hline 01 & 1,050 & & & & $1,007.5$ \\
\hline O 2 & 950 & & & & 917.0 \\
\hline
\end{tabular}


の深度を水頭の基準にとった。

\section{4. 問題の定式化}

本研究では带水層の貯留係数が一様比与兄られている 場合に括ける透水量係数を推定する問題について考察す 万。

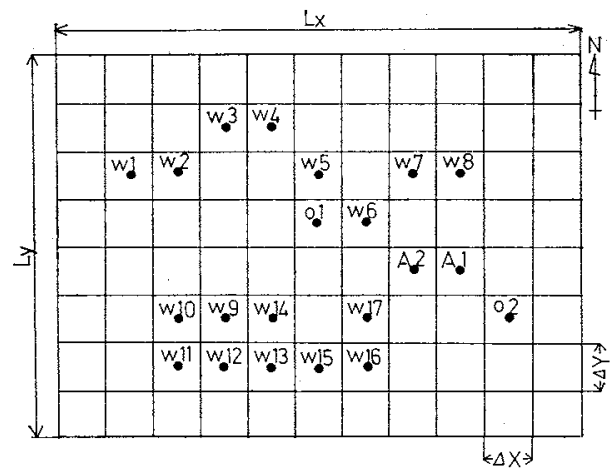

図 3 水平二次元带水層モデル，差分格子座整，坑 并位置

$\mathrm{G}_{6}$ 層は被压された带水層であり，てこには生産井， 還元井が完全に貫入しているものとすると $\mathrm{G}_{6}$ 層は图 3 に示すように水平二次元のモデルで表せる。したがって 流動方程式は次のよらに与光ら和る。

$$
\frac{\partial}{\partial x}\left(T \frac{\partial H}{\partial x}\right)+\frac{\partial}{\partial y}\left(T \frac{\partial H}{\partial y}\right)=S \frac{\partial H}{\partial t}+Q
$$

この式は次の初期括よび境界条件の下で差分法により 解かれる。

初期条件 : $H(x, y, 0)=H_{i}$

境界条件：透水性の場合， $H=$ const.

不透水性の場合, $\frac{\partial H}{\partial x}=\frac{\partial H}{\partial y}=0$

ここで $T$ は透水量倸数, $H$ は水頭, $S$ は眝留係数， $Q$ は揚水量季たは圧人水量， $t$ は時間， $x, y$ は直交座標, $L_{x}, L_{v}$ はそ狆ぞれ带水層の $x$ 方向, $y$ 方向の距離, $H_{i}$ は 初期水頭である。

い最適透水量係数を決定するために次に定義する目 的関数 $J$ 賽入する。

$$
J=\sum_{l=1}^{M} \int_{t_{0}}^{t_{1}}\left[H_{o b, l}(t)-H_{c a l}\left(x_{l}, y_{l}, t\right)\right]^{2} d t
$$

ここで $H_{c a l}$ は水頭の計算值, $H_{o b}$ は測定值，下添字の しは坑井位置の指標，M以坑井数である。

$$
\text { そこで次の制約条件 }
$$

$$
T(x, y) \geqq 0
$$

と上記の式(2)〜(5)を渶足するよらにJの值を最小化する ことによってTの最適值が決定される。

\section{5. 透水量係数の算定法}

準線形近似法 (DISTEFANO，et al., 1975) 炕よる最 適透水量係数の算定法化ついて述べる。

一般に水頭 $H$ は透水量係数 $T$ や詝留係数 $S$ の関数であ るが，前述のよらに本研究では $S$ て定としたことによ りHはTのみの関数となる。

いを最小二乗法の原理を用いて $M$ 個の水頭測定値から $m$ 個のTの值を推定する。ただし $m$ は $M$ の 2 3 倍程度 である(JAHNS，1966)。ここで $m$ 個の $T$ で構成される 列ベクトル

$$
\boldsymbol{T}=\operatorname{Col}\left[T_{1}, T_{2}, \cdots \cdots, T_{m}\right]
$$

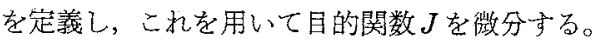

$$
\begin{aligned}
\frac{\partial J}{\partial T_{i}}= & -2 \sum_{l=1}^{M} \int_{t_{0}}^{\iota t}\left[H_{o b, l}(t)-H_{c a l}\left(x_{l}, y_{l}, t\right)\right] \\
& \times \frac{\partial H_{c a l}\left(x_{l}, y_{l}, t\right)}{\partial T_{i}} d t
\end{aligned}
$$

ただし $i=1 \sim m$.

$J$ の最小继を求めるためには式(9)がゼ口となる解を求 めればよい。しかし式(9)は非線形方程式であるので，て れを次のように線形化しなければならない。

まずHを次のように線形近似する。

$$
\begin{gathered}
H_{c a t}\left(x_{l}, y_{l}, t, T^{n+1}\right)=H_{c a t}\left(x_{l}, y_{l}, t, T^{n}\right) \\
+\left(\operatorname{grad}_{T} H_{c a l}\left(x_{l}, y_{l}, t, T^{n}\right), \Delta T^{n+1}\right)
\end{gathered}
$$

ただし

$$
\begin{aligned}
& \Delta T^{n+1}=T^{n+1}-T^{n} \\
& T^{n}=\left(\begin{array}{c}
T_{1}^{n} \\
T_{2}^{n} \\
\vdots \\
T_{m}^{n}
\end{array}\right)
\end{aligned}
$$

$$
\operatorname{grad}_{T} H_{c a l}\left(x_{t}, y_{l}, t, T^{n}\right)=\left(\begin{array}{c}
\frac{\partial H_{c a l}\left(x_{l}, y_{l}, t, T^{n}\right)}{\partial T_{1}^{n}} \\
\frac{\partial H_{c a l}\left(x_{l}, y_{l}, t, T^{n}\right)}{\partial T_{2}{ }^{n}} \\
\vdots \\
\frac{\partial H_{c a l}\left(x_{l}, y_{l}, t, T^{n}\right)}{\partial T_{m}^{n}}
\end{array}\right)
$$

ここで上添字の $n$ は計算の反復回数, $\operatorname{cgrad}_{T} H_{c a l}\left(x_{l}\right.$, $\left.\left.y_{l}, t, T^{n}\right), \Delta T^{n+1}\right)$ は, ベクトル $\operatorname{grad}_{T} H_{c a l}\left(x_{l}, y_{l}, t, T^{n}\right)$ と $\Delta T^{n+1}$ の内積を意味する。

式(9)に式(10)を代入し整理すると線形方程式が得ら れる。

$\sum_{j=1}^{m} \sum_{i=1}^{M} \int_{i_{0}}^{t_{1}} \frac{\partial H_{c a t}\left(x_{i}, y_{l}, t, T^{n}\right)}{\partial T_{i}^{n}} \frac{\partial H_{c a l}\left(x_{l}, y_{\imath}, t, T^{n}\right)}{\partial T_{j}^{n}}$

$$
\begin{aligned}
& d t \Delta T_{j}{ }^{n+1}=\sum_{l=1}^{M} \int_{t_{\theta}}^{t s}\left[H_{o b, l}(t)-H_{c a l}\left(x_{l}, y_{i}, t, T^{n}\right)\right] \\
& \frac{\partial H_{c a b}\left(x_{l}, y_{l}, t, T^{n}\right)}{\partial T_{i}^{n}} d t
\end{aligned}
$$


式(11)をマトリクス表示すれぱ

$$
A^{n} \Delta T^{n+1}=B^{n}
$$

となる。ただし

$$
\begin{aligned}
& A^{n}=\left(a_{i, j}\right) \\
& B^{n}=\left(b_{i}^{n}\right)
\end{aligned}
$$

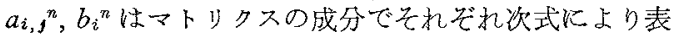
される。

$$
\begin{aligned}
a_{i, j}{ }^{n} & =\sum_{l=1}^{M} \int_{t_{0}}^{t} \frac{\partial H_{c a l}\left(x_{i}, y_{l}, t, T^{n}\right)}{\partial T_{i}^{n}} \frac{\partial H_{c a l}\left(x_{l}, y_{l}, t, T^{n}\right)}{\partial T_{j}^{n}} d t \\
b_{i}^{n}= & \sum_{i=1}^{M} \int_{t_{0}}^{t_{1}}\left[H_{o b, l}(t)-H_{c a l}\left(x_{l}, y_{l}, t, T^{n}\right)\right] \\
& \frac{\partial H_{c a l}\left(x_{l}, y_{l}, t, T^{n}\right)}{\partial T_{i}^{n}} d t
\end{aligned}
$$

式(12) 学解いて修正值 $\Delta T^{n+1}$ が求められる。したが って区復回数 $n+10$ とのTの值性次式で与兄られる。

$$
T^{n+1}=T^{n}+\Delta T^{n+1}
$$

本計算では $\operatorname{grad}_{T} H$ は次の差分近似式により求められ た。

$$
\begin{aligned}
& \frac{\partial H(x, y, t, T)}{\partial T_{i}} \\
& \doteqdot \frac{H\left(x, y, t, T+\Delta T \cdot e_{i}\right)-H(x, y, t, T)}{\Delta T \cdot e_{i}}
\end{aligned}
$$

ここで $e_{i}$ は $i$ 番目の単位ベクトルである。

計算を行らにあたって特炷意を要することは， $T^{n+1}$ の値は前述の制約条件（式(7)）を満足し， $\Delta T$ は $H$ 值 を十分変化さ好ると同時に式(14)0一次近似を成立さ也 るような小さな值でなければならない。そこで $\Delta T=\alpha \cdot T$ と表し， $\alpha$ の值を $10^{-4} \sim 10^{-14}$ の範井で種々変えて試行 錯愦的に $\operatorname{grad}_{T} H$ を計算した。

Tの最適值を決定するための計算手順を以下に示す。

(1) 初わに全計算領域のTの値として一様に任意の值 を与克る。

(2) 前述の算定法によりJの值が最小となるよらにT の倠を修正する。

（3）(2)の段階で得られた $T$ の值を用いて $H$ を訪算す る。

(4) 次にJの値を計算する。

(5) Jの值が許容誤差内にあるかどらかを判定する。 許容誤差内にあれば計算を終了しTH決定される。もし

\begin{tabular}{|c|c|c|c|}
\hline 坑井 名 & $\begin{array}{c}\text { 昭和 } 57 \text { 年 } 12 \text { 月 } \\
\text { 静 止 水 頭 } \\
\mathrm{m}\end{array}$ & 坑井 名 & $\begin{array}{c}\text { 昭和 } 57 \text { 年 } 12 \text { 月 } \\
\text { 静 止 水 頭 } \\
\mathrm{m}\end{array}$ \\
\hline W 1 & $1,084.3$ & W12 & $1,100.3$ \\
\hline W 2 & $1,083.1$ & W13 & $1,100.0$ \\
\hline W 3 & $1,078,0$ & W14 & $1,099.4$ \\
\hline W 4 & $1,100.0$ & W15 & $1,097.7$ \\
\hline W 5 & $1,083.0$ & W16 & $1,096.4$ \\
\hline W 6 & $1,085.1$ & W17 & $1,095.8$ \\
\hline W7 & $1,089.0$ & A 1 & 浿 \\
\hline W 8 & $1,088.7$ & A 2 & $1,091.5$ \\
\hline W 9 & $1,099.7$ & O 1 & $1,084.0$ \\
\hline W10 & $1,096.2$ & O 2 & $1,089.0$ \\
\hline W11 & $1,102.1$ & & \\
\hline
\end{tabular}
許容䜋差内になければ，(1)の段階に戻り，計算領域をさ らに緗かく分割し，その段階まで火得られたTの值を初

\begin{tabular}{|c|c|}
\hline 分割 数 & $J$ の 值 $\mathrm{m}^{2}$ \\
\hline 1 & 22,240 \\
\hline 2 & 17,610 \\
\hline 4 & 14,460 \\
\hline 8 & 7,978 \\
\hline 16 & 3,062 \\
\hline 44 & 3,027 \\
\hline
\end{tabular}
期推定值として与再び許容誤差内になる⿱で以上の手 順を反復する。

\section{6. 透水量係数の分布}

$\mathrm{G}_{6}$ 䈐の計算対象領域 $\left(L_{x}=5,500 \mathrm{~m}, L_{y}=4,000 \mathrm{~m}\right)$ を 図 3 に示すような差分格子座標 $(\Delta x=\Delta y=500 \mathrm{~m})$ で表
表 2 生産停止時における水頭の測定値(昭和57年12月)

表 3 計算領域の分割数と $J$ の值

Lた。

境界条件：前述の上うに $\mathrm{G}_{8}$ 層は海抙線近傍で尖隇 ていることから計算領域の北側境界を不透水性 ( $\partial H / \partial y$ $=0)$ とし，その他の3つの境界を透水性（ $H=$ const.） と与えた。な和差分格子坐標上では実際の㐾井位䁂は格 子ブロックの中心にとった(図 3 参照)。

初期条件：差分格子上の初期水頭は次の上5に与光 た。亦ず昭和 57 年12月に生産を一版停止したときの各坑

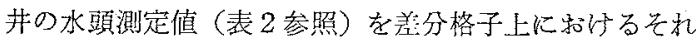
ぞれの坑井ブロックの初期水頭として与光た。次に生産

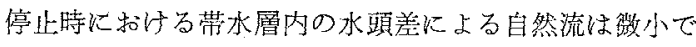
あると考光て，計算領域の南僋，東側，西側の3つの境 界も北側境界と同様に不透水性と与之た。以上の上らな 境界条件の下で, 前述の式(2)に括いて非定常項 $\partial H / \partial t$ 和 よびソース項 $Q$ をゼ口，透水量俰数 $T$ を一様に与えた式 を解き，その定常解をその他の放子ブロックの初期水頡 值として与えた。

以上の初期及び璄界条件の下で，図 3 亿示す揚承量お よび圧入水量の湘定值，水頭の算定值を用いて，前述の 算定法により $\mathrm{G}_{6}$ 層の透水量係数 $T$ を推定した。表 3 K 以計算領域の透水量係数の初期推定值と乙て $T=9.6 \times$ $10^{-4} \mathrm{~m}^{2} / \mathrm{s}$ を与兄て, 領域の分割数を $2,4,8,16,44$ と順次 細かくしたときの目的関数 Jの值を示す。分割数をこれ 


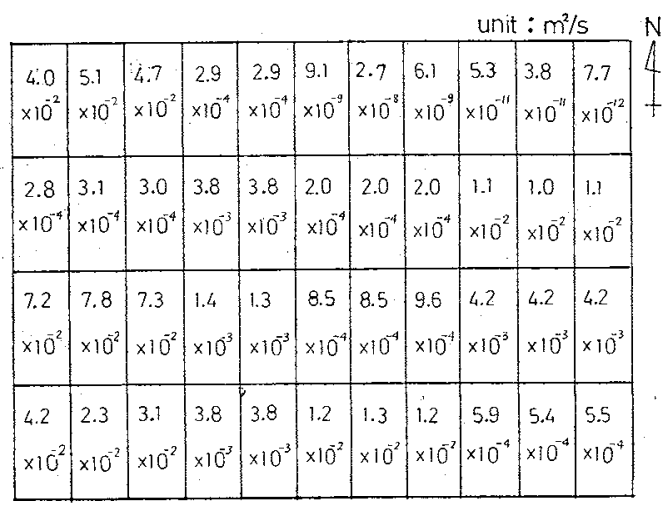

图 $4 \mathrm{G}_{6}$ 層の透水量係数の推定值の分布

以上細かくしてもJの值は減少しなかったので本計算で は $\mathrm{G}_{6}$ 層のTの分布の最適值として44分割のときの值を 採用した。その結果を图 4 亿示寸。この分布をみると領 域の北側境界の一部に扣いて $T$ の值方 $10^{-12} \sim 10^{-9} \mathrm{~m}^{2} / \mathrm{s}$ のオーダの值で極端に小さくなっているがそれ以外の大 部分の領域では $10^{-4} \sim 10^{-2} \mathrm{~m}^{2} / \mathrm{s}$ のオダの值である。 この值から，いま層厚の平妈を $40 \mathrm{~m}$ (天然がス鉱業新潟 支部，1973）として透水係数を求めると $5.0 \times 10^{-6} \sim 2.0$. $\times 10^{-8} \mathrm{~m} / \mathrm{s}$ の範囲の值が得られる。この值は, 前述の ように $\mathrm{G}_{8}$ 層が碩岩，粗稙砂交り細碩岩からなることを 考えれば，妥当の值であると思小れる(建設産業調查会， 1980)。な打 $J$ 倠 $\left(3,027 \mathrm{~m}^{2}\right)$ から水頭の測定值と計算 值との平均䛊差は約 $\pm 3.6 \mathrm{~m}$ と概算された。

\section{7. 透水量係数の精度}

前述の透水量係数Tの堆定值の精度について考察する ために次の模擬計算を行った。まず应 5 に示すよらに前 述の $\mathrm{G}_{6}$ 層の計算領域と同じ大ささ, 坑井配置の領域に 図 5 のカッコ内の数字で示すよらなTの分布を与克, こ

\begin{tabular}{|c|c|c|c|c|c|c|c|c|c|c|}
\hline 1.8 & 2.4 & 2.3 & 3.5 & 3.3 & 3.8 & 4.4 & 3.8 & 50.0 & 48.0 & 47.0 \\
$(2.3)$ & $(2.7)$ & $(2.9)$ & $(3.5)$ & $(3.7)$ & $(4.2)$ & $(4.4)$ & $(4.6)$ & $(5.4)$ & $(6.2)$ & $(5.8)$ \\
\hline
\end{tabular}

图 5 模拨計算に扣ける透水量係数の真值(カッコ内) 执上び推定值の分布

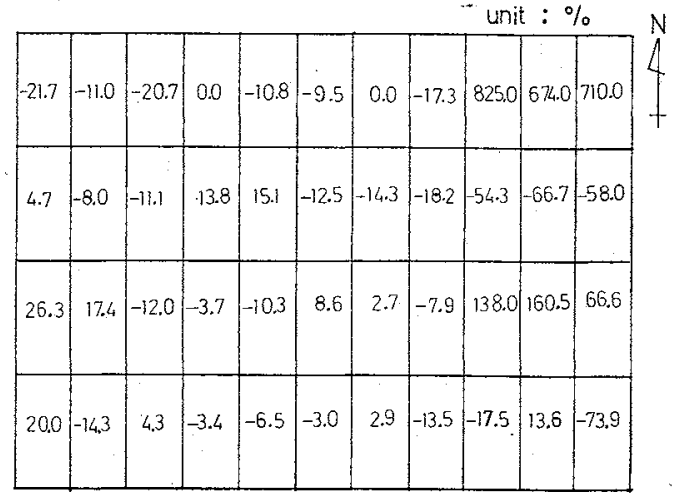

图 6 、模擬計算に打计る透水量係数の推定值と真值 の相対愦差

れを本領域に和计る透水量係数の真值 $T_{t r}$ と仮定する。 また各玾并の揚水量执よび厌入水量には前述の図 2 に示 す測定值を用いて式(2)により各格子ブロックの水頭を計 算し,この計算値各坑井の測定值 $H_{0 b}$ と仮定した。 たたしこの計算で住初期和よび境界条件快図 3 の計算領 域と同様に与竞た。この $H_{o b}$ *の值を利用して $T$ を算定 した結果，44分割のときの目的関数が $J=2.3 \times 10^{-15} \mathrm{~m}^{2}$ となり，Tの推定値はほとんど真值と一致した。

次に測定值には誤差が含まれているものと考えて上記

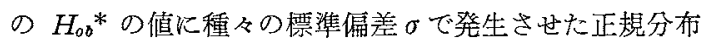
$N\left(\mu, \sigma^{2}\right)$ (ここで $\mu$ は平均) の乱数を愦差 $e$ として加壳， それを水頭の測定值 $\left(H_{o b}=H_{o b}{ }^{*}+e\right)$ とててTの推定を 行った。その結果，標準偏差 4.9 で発生さ謎た正規分布 $N\left(0,4.9^{2}\right)$ の乱数の虽差を加えた水頭(こ秃性水頙に $-4.9 \mathrm{~m} \sim 4.9 \mathrm{~m}$ の範用内の誤美を 68\% 含むことを意味 する）を利用したとさの目的関数の値が $J=3,072 \mathrm{~m}^{2}$ で めり，前述の $\mathrm{G}_{6}$ 層の最適透水量係数のときの $J$ の值 $\left(3,027 \mathrm{~m}^{2}\right)$ K近い。このときのTの計算結果を図 5 に示 す。また透水量係数の推定值 $T_{c a l}$ と真值 $T_{b r}$ を比較す るために雨者の相対䛊差 $\varepsilon\left(=\left(T_{c a b}-T_{t r}\right) / T_{t r}\right)$ を計算し

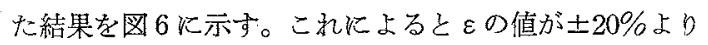
小さい領域が全領域の約 $75 \%$ を占めている。

以上のよらに模擬計算と前述の $\mathrm{G}_{6}$ 周の計算に和ける $J$ の值が伍济同じであることから， $\mathrm{G}_{6}$ 層の透水量係数 の推定值（図 4) は，模擬計算の精度と同程度で离万う と推測される。これは今回入手した生産データの精度か

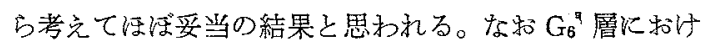
るTの推定值の精度に関する主な問題点として次のこと があげられる。

（1）今回利用した生産データの精度が悪いこと

(2) 生産井就よび還元井の流動坑底压力の算定值の精 度を確認できなかったこと 
（3）坑底圧力を水頭に換算する際にすべての抗井にお ける坑口の標高を一様に海水面にとったこと

(4) $\mathrm{G}_{6}$ 層の計算領域の南側境界では第二次企業化実 験井の干涉が考光ら机ること

(5) 本計算領域の初期水頭に式(2)の計算による定常解 を用いたこと

今後さらにTの推定值の精度を高めるためには以上の 5つの点炕ついて総合的に検討されねばならない。

\section{8.あとがき}

本研究では，新潟県西蒲原地区水溶性ガス田に蚂けるる 揚水量, ガス水比などの生産データから算定された水頭 の値を利用して，準線形近似法により $\mathrm{G}_{6}$ 層の透水量係 数の空間分布を推定した。その結果透水量保数の推定檤 は $2.0 \times 10^{-4} \sim 7.8 \times 10^{-2} \mathrm{~m}^{2} / \mathrm{s}$ の範网の值であった。そ の推定值の精度は, 標準偏差 4.9 で発生させた正規乱数 の誤差を合导水頭湘定值から推定された透水量倸数の精 度に添淩等しいものと推测された。

今後生産データの誤差, 流動坑底圧力の算定精度, 計 算領域の境界及び初期条件の与方なぼを総合的に険討 することによってさらに高い精度の結果が得られるもの と思われる。

\section{参考·文 献}

K,H. CoATS and J.H. Henderson, 1970: A new technique for determining reservoir description from field performance data, Trans., AIME, 249, 66-74.

L. BECKER and W.W-G. YEH, 1972: Identification of parameters in unsteacly open channel flows, Wat. Res. Res., 8(4), 956-965.

N. Distefano and A. Rath, 1975: An identification approach to surface hydrological systems, Wat. Res. Res., 11(6), 1005-1012.

J. ORKISZEWSKI, 1967: Predicting two-phase pressure drops in vertical pipe, JPT, Aug., 829-838.

本間 仁, 安芸䅧一編, 1962 : 水理学, 岩波書店, 173 . 東邦天然ガス侏，1985：社内凟料。

天然ガ 鉿業会新潟支部，1973：非排水方式に上る水溶 性天然ガス企業化実験中間報告書.

新潟罻生活環境部公害規制課, 1984 : 新潟平野の地盤沈 下, 1-11.

G.E. Forsythe, M.A. MAlcolm, C.B. Moler (森 正武訳), 1978 : 計算機のための数値計算法, 科学技術 出版社, 82-91.

H.O. JAHNS, 1966: A rapid method for obtaining a two-dimensional reservoir description from well pressure response data, SPEJ, Dec., 315-327.

地下水ハンドブック編集委員会, 1980：地下水ハンドブ ック，建設産業調查会，287. 